\title{
Effect of pre-treatments on solar drying kinetics of red seedless grapes (cv. Monukka)
}

\author{
Inês N. Ramos ${ }^{\mathrm{a}}$, Teresa R.S. Brandão ${ }^{\mathrm{a}}$, And Cristina L.M. Silva ${ }^{\mathrm{a}^{*}}$ \\ ${ }^{a}$ CBQF - Centro de Biotecnologia e Química Fina - Laboratório Associado, Escola Superior de Biotecnologia, \\ Universidade Católica Portuguesa/Porto, Rua Dr. António Bernardino Almeida, 4200-072 Porto, Portugal \\ ${ }^{*}$ Corresponding author \\ clsilva@porto.ucp.pt \\ TEL: +351225580058 \\ FAX: +351225090351
}

Received: 16 April 2014; Published online: 18 October 2014

\begin{abstract}
Two different pre-treatments were applied to grapes prior to drying in a mixed mode solar dryer. Grapes were blanched in water and in a $0.1 \%$ sunflower oil water emulsion, both at $99^{\circ} \mathrm{C}$ and for approximately 15 seconds. Several models were tested to fit the experimental data of drying curves but the normalized Newton model gave the best fit results. Samples blanched in hot water or in the $0.1 \%$ edible oil emulsion had faster drying rates than untreated samples. Contrary to what was expected, pre-treating with the $0.1 \%$ edible oil emulsion did not increase the drying rate to a higher extent than blanching. Pre-treatments did not give a noteworthy difference in the total drying time. However, they had an important role in accelerating initial drying rates, thus preventing moulds and bacterial growth and consequently increasing farmers' income.
\end{abstract}

Keywords: Pre-treatments; Solar drying; Kinetics; Modeling; Raisins 


\section{Nomenclature}

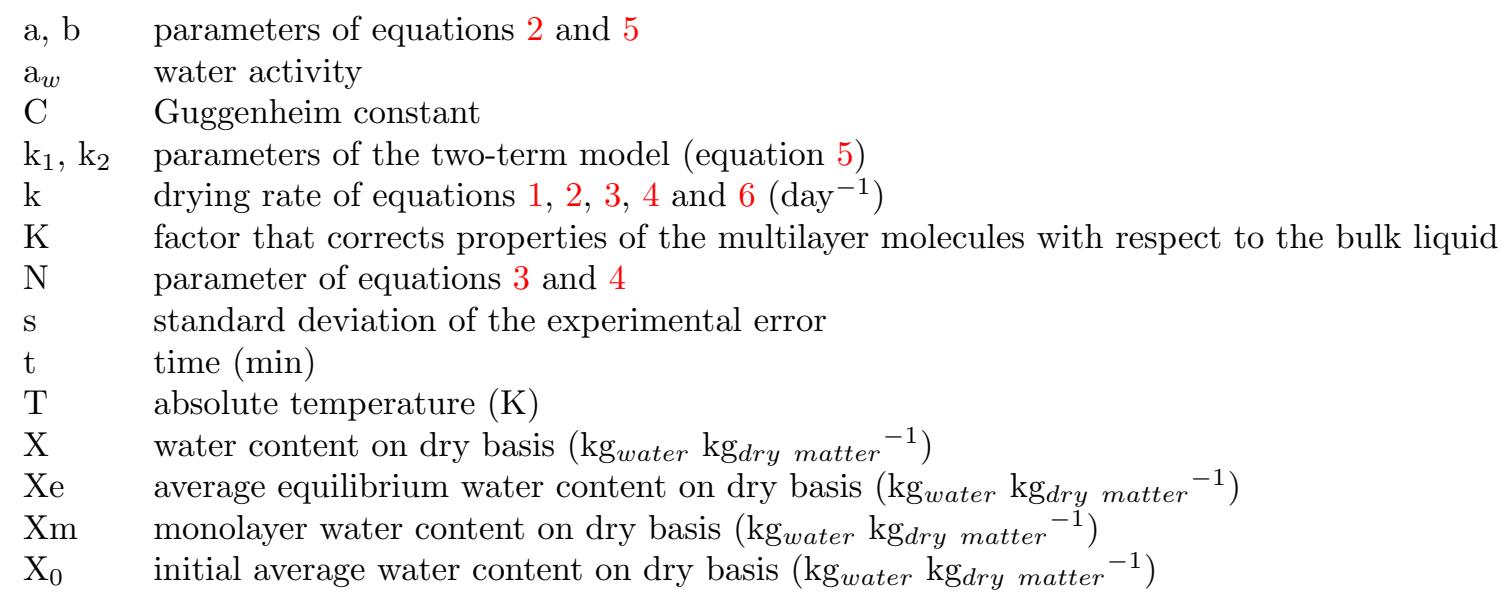

\section{$1 \quad 1$ Introduction}

2 Fruits are an essential part of a healthy human diet but mostly forgotten by a fast-living soci4 ety. This gap may be bridged to a large extent 5 by consuming dried fruits which are convenient. 6 Dried grapes have functional properties due to their high concentrations of polyphenols, antioxidants, flavonoids and minerals (Williamson \& Carughi, 2010).

- Over the years, several empirical treatments were applied to grape berries prior to drying, such as oil-surfactant emulsions, caustic treatments, sulphuring or olive oil. Pre-treatments usually have a dual effect to accelerate the drying rate and, most of the time, improve quality (Grncarevic \& Radler, 1971). Acceleration of the drying rate reduces total drying time and consequently increases production. On the other hand, quality improvement is mainly achieved by generating light-coloured raisins with better sanitation (Pangavhane, Sawhney, \& Sarsavadia, 1999).

Pre-treatments may be applied using a 'hot' or 'cold' technique, where 'cold' dipping is carried out with immersions at ambient temperature. 'Hot' dipping increases the drying rate to a faster extent than 'cold' dipping, however, cracks in the waxy cuticle originate which diminish the quality of produced raisins. 'Cold' dipping improves their quality by giving rise to an attractive colour make-up, without damaging the berries. 'Cold dip' treatments used alkaline oil emulsions, with olive oil and wood ashes, in ancient times
33 but nowadays they are prepared with specially 34 formulated drying oils ('dipping oils') and food 35 grade potassium carbonate $\left(\mathrm{K}_{2} \mathrm{CO}_{3}\right)$ (Whiting, 6 1992). The drying oils are derived from ani7 mal tallow or vegetable oil, and mainly consist of ethyl oleate and oleic acid. Ethyl oleate is widely used in 'cold' dipping, due probably to its inoffensive nature when compared with other food additives such as sodium hydroxide $(\mathrm{NaOH})$ or sulphur. This product is an oil-surfactant which changes the waxy layer structure of grape skin 4 thus expediting the drying process and reducing browning. The ethyl oleate effect on air-drying kinetics of raisins has been pointed out by several authors to accelerate drying rates (Mahmutõglu, 8 Emir, \& Saygi, 1996; Pangavhane et al., 1999; 49 Ponting \& Mcbean, 1970; Saravacos, Marousis, o \& Raouzeos, 1988; Peri \& Riva, 1984).
Blanching (or dipping in plain hot water) increases drying rate, by removing or breaking the cuticular wax and inducing cracks in the grape skin (Striegler, Berg, \& Morris, 1996). It has the advantage of not adding chemicals to grapes, thus giving a more 'natural' product.

Most grapes are usually dried using solar energy. There are several different solar dryers, including direct, indirect and mixed modes (Fuller, 1993; Bala \& Woods, 1994). An extensive review of solar dryers, applied to food drying at small scale, was compiled by Murthy (2009). Modelling is essential to design solar dryers, and to predict and simulate drying processes. An overview of 
Effect of pre-treatments on kinetics of solar dried grapes $\mid 241$

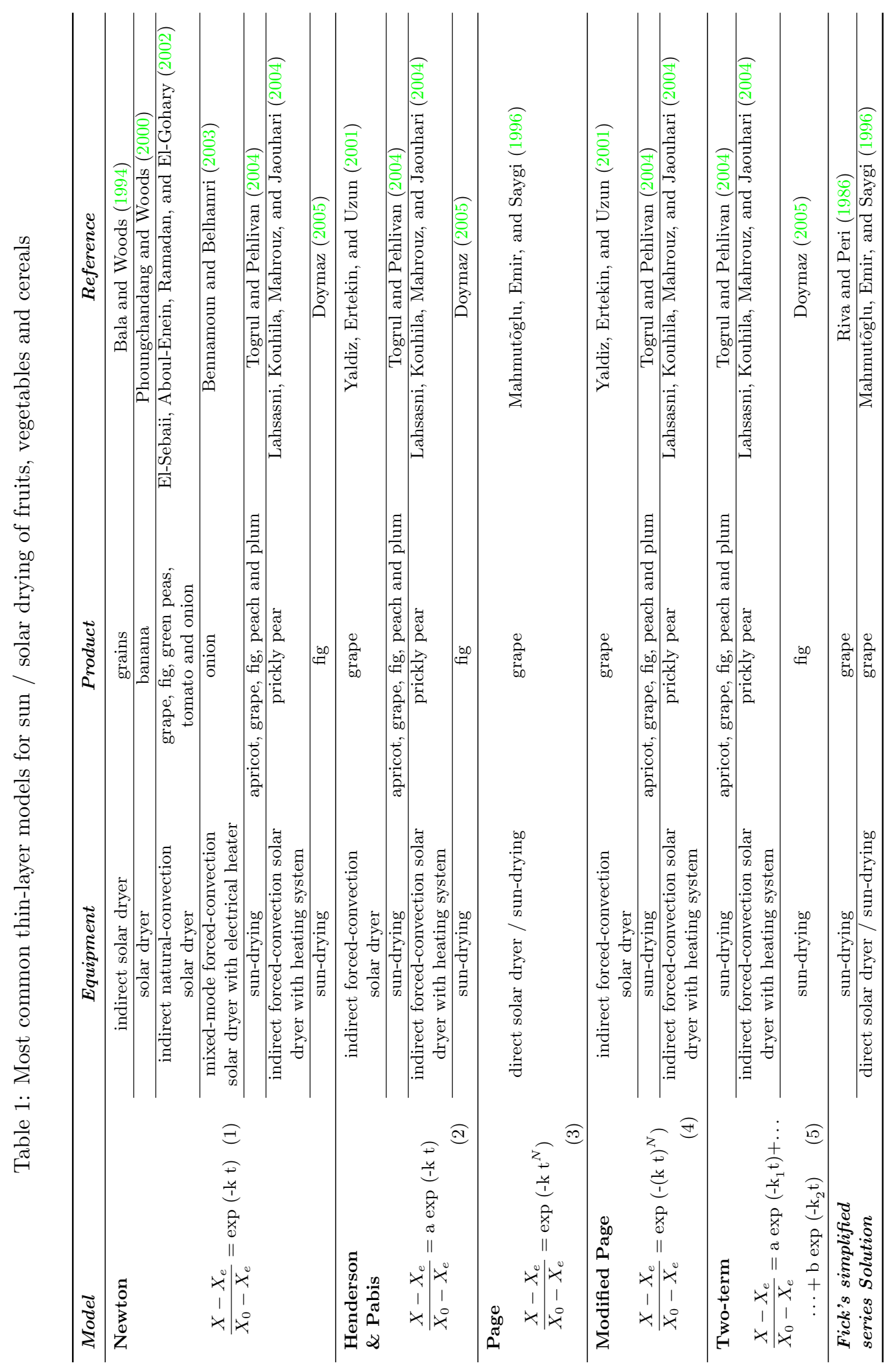

IJFS | October 2014 | Volume 3 | pages 239-247 
the most widely used models for sun / solar drying of fruits, vegetables and cereals in thin-layer is presented in Table 1, including type of equipment and dried products. The models include: an equation analogous to the Newton's law of cooling and first applied to drying by Lewis, also known as the Exponential model (equation 1); the Henderson and Pabis model (equation 2), similar to the first term of the Fick's series solution; the Page (equation 3) and modified Page (equation 4) models; the two-term model (equation 5) and the Fick's simplified series solution.

Some of these models were tested to achieve the main objective of this work, which was to quickly assess kinetics and total drying time for the field solar drying of grapes submitted to different pretreatments.

\section{Materials and Methods}

\subsection{Description of the solar dryer}

This study was carried out in a solar drier at Mirandela in Northern Portugal (Direcção Regional de Agricultura de Trás-os-Montes) (Fig. 1). According to the classification of Fuller (1993), this is a mixed mode or hybrid cabinet dryer. The solar dryer consisted of a collector for pre-heating the air, a drying chamber and a solar chimney. It is made of wood, with a transparent plastic film (polyethylene) cover (Araújo et al., 1994), and is $8.10 \mathrm{~m}$ long, $7.50 \mathrm{~m}$ wide and 2 to $2.6 \mathrm{~m}$ high. The dryer's collector faced south to maximise solar radiation, and formed an angle of 38 degrees, which is similar to local latitude. It had a $30 \mathrm{~cm}$ opening over all its length, for air entrance. In this area, the air is pre-dried before moving to the dehydration chamber. The drying chamber comprises 18 (6x3) sets of 5 trays each (90 trays total). Two exhaust air fans are placed on the back wall.

\subsection{Description of grape samples}

Red seedless grapes from the Monukka cultivar were purchased from a local farmer in the region (Trás-os-Montes, Portugal). Grape clusters were cut into smaller pieces and the bigger peduncles removed. Some of the grapes were blanched in hot water or in a $0.1 \%$ water emulsion of sunflower oil, (3às Sovena) both at $99^{\circ} \mathrm{C}$ and for approximately 15 seconds. These preparative techniques are shown in Fig. 2. The proportion of grapes to solution was approximately 2 $\mathrm{kg} \mathrm{l}^{-1}$ and the bath temperature was monitored. The remaining grapes were washed in cold water (untreated samples). These pre-treatments were chosen with the aims to obtain a 'more natural' product and easier application in the available facilities close to the solar dryer.

Determination of the grapes' initial water content (berries with small peduncles) was performed according to the AOAC - 984.25 method (AOAC, 2000), and water content during drying was mathematically calculated. The grapes' initial dimensions were measured using a sliding vernier calliper (Measy 2000 Typ 5921, Swiss), and the Brix Degree (g sucrose/g solution) of fresh grapes was determined in triplicate with a hand refractometer (Atago, Tokyo, Japan).

\subsection{The drying experiments}

The pre-treated material was weighed and divided between the wood trays (approximately $5 \mathrm{~kg}$ per tray). The initial load was approximately $250 \mathrm{~kg}$ of grapes. The mass of samples was daily determined using a farmer's weighing device, with $\pm 100 \mathrm{~g}$ accuracy, until reaching a constant value. Four replicates were performed in the solar dryer for each pre-treatment.

Six K thermocouples and two air humidity probes were placed in different positions of the solar drier. Temperature and air humidity were acquired on-line by a squirrel datalogger (Grant Instruments 1023, Cambridge, England) every 15 minutes. Air velocity was determined with a vane anemometer, with $\pm 0.01 \mathrm{~m} \mathrm{~s}^{-1}$ accuracy (Airflow LCA 6000, Buckinghamshire, England), twice a day.

\subsection{Modelling considerations}

Several models were tested to fit drying data, including the two-term model, the Newton model, and two simplified forms of the series solution of Fick's diffusion equation, with one term and two terms. The Newton model was normalised 


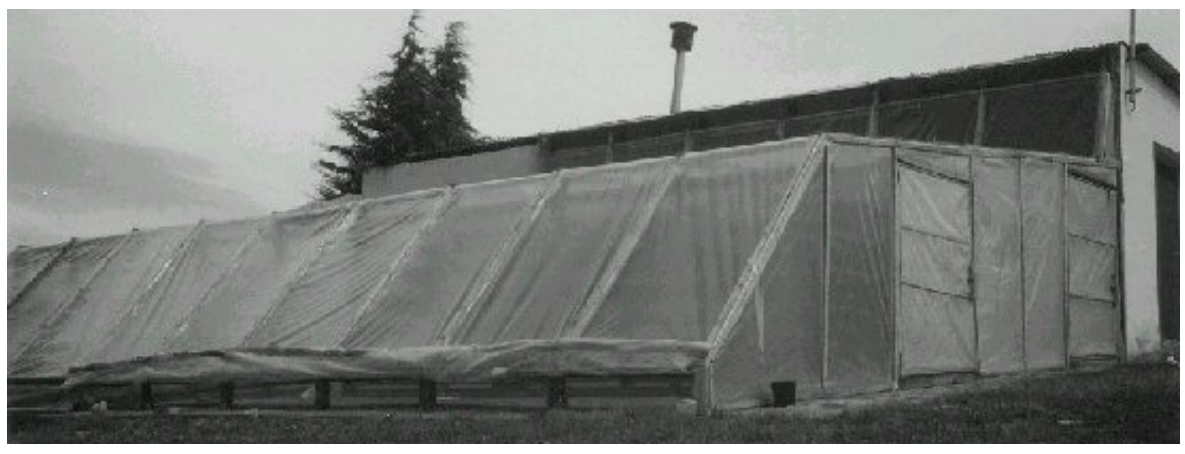

Figure 1: Solar dryer located in Northern Portugal - Mirandela
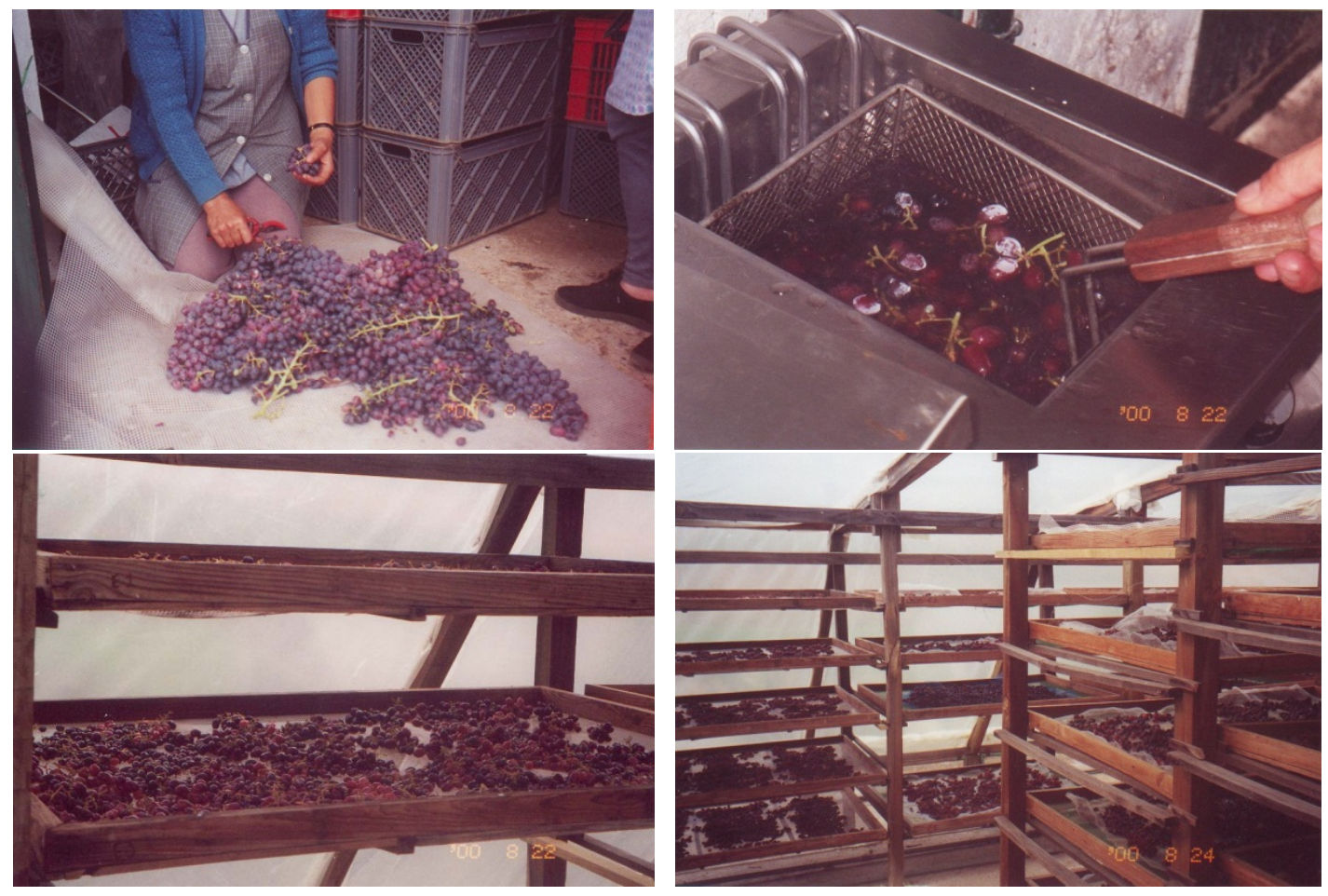

Figure 2: Preparative techniques for solar drying 
to the initial water content, in order to allow a clearer comparison between pre-treatments (equation 6):

$$
\frac{X}{X_{0}}=\frac{X_{e}}{X_{0}}+\left(1-\frac{X_{e}}{X_{0}}\right) \exp (-\mathrm{k} \mathrm{t})
$$

where $X$ is the average water content on dry basis

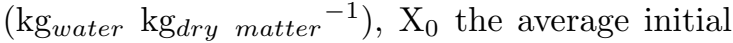
water content, $X_{e}$ the average equilibrium water content, $\mathrm{k}$ the drying rate $\left(\mathrm{day}^{-1}\right)$ and the time $(\min )$.

The average equilibrium water content value for grapes' drying, to include in the normalised Newton model, was determined by the GAB equation (7), using data from grape sorption isotherms presented by Vázquez, Chenlo, Moreira, and Carballo (1999).

$$
\frac{X_{e}}{X_{m}}=\frac{\mathrm{C} \mathrm{K} a_{w}}{\left(1-\mathrm{K} a_{w}\right)\left(1-\mathrm{K} a_{w}+\mathrm{CK} a_{w}\right)}
$$

$X m$ is the water content on a dry basis corresponding to the monolayer value, $C$ the Guggenheim constant, $\mathrm{a}_{w}$ the water activity and $K$ a factor correcting properties of the multilayer molecules with respect to the bulk liquid (Bizot, 1983). C and K reflect the temperature effect.

\subsection{Statistical Analysis}

The drying rate $(k-$ in equation 6$)$ was estimated by non-linear regression analysis using the package Solver of MICROSOFT Excel 2002 (Microsoft ${ }^{\circledR}$ Corporation, Redmond, WA, USA). The $95 \%$ standard error of the parameter (SE) and statistical indicators of the quality of the regression [coefficient of determination $\left(\mathrm{R}^{2}\right)$ and standard deviation of the experimental error $(\mathrm{s})]$ were also calculated (Box, Hunter, \& Hunter, 1978). The evaluation criterion for selecting the best model was the standard deviation of the experimental error (s).

\section{Results and Discussion}

The grapes' initial average diameter was $1.50 \pm$ $0.14 \mathrm{~cm}$, and the initial water content ranged from $81.0 \% \pm 1.3$ (wet basis), $83.0 \% \pm 1.6$ and $83.0 \% \pm 2.0$, respectively for untreated grapes, grapes blanched in hot water and grapes blanched in the edible oil solution. Brix Degree ranged between $19.0 \% \pm 0.9$ for the fully ripened grapes and $13.0 \% \pm 1.2$ for unripe grapes. Air velocity in the solar dryer ranged between 9 and $34 \mathrm{~cm} \mathrm{~s}^{-1}$ (respectively measured in the front and back of the solar dryer). For an average air temperature of $25.38^{\circ} \mathrm{C}$ and average air relative humidity of $44.21 \%$, observed during the field experiments, the value of $0.0677 \mathrm{~kg}_{\text {water }} \mathrm{kg}_{d r y}$ matter ${ }^{-1}$ was calculated for the equilibrium water content, using the GAB equation (equation 7).

Of all the tested models, the normalized Newton model (equation 6) was the one that best fitted the data for experimental drying curves, with the lowest standard deviation of the experimental error $(\mathrm{s})$. Table 2 presents the estimated values for drying rate $(\mathrm{k})$ of the Newton model, the corresponding $95 \%$ standard error of the parameter (SE), the coefficient of determination $\left(\mathrm{R}^{2}\right)$ and the standard deviation of the experimental error (s) for each grapes' pre-treatment.

The plots of the fits of the normalized Newton model to the three series of data (untreated and two pre-treatments) are shown in Fig. 3. The two lower curves corresponding to blanched samples in hot water and edible oil solution are overlaid, due to very similar drying rates (Table 2). One concludes that blanching samples in hot water enhanced the drying rate, in comparison with untreated samples. This is in accordance to what was reported in the literature (Aguilera, Oppermann, \& Sanchez, 1987; Striegler et al., 1996). Drying rates of samples blanched in the $0.1 \%$ sunflower oil emulsion are also faster than the ones for untreated samples. It was expected that immersing grapes in the sunflower oil emulsion would expedite drying to a larger extent than simple water blanching. Sunflower oil consists of oleic acid and, as mentioned before, this oilsurfactant changes the waxy layer structure of grape skin and is one of the main constituents of commercial drying oils. However, commercial drying oils are usually used in 'cold' dipping. The results indicate that if a 'hot' dipping is planned, the addition of sunflower oil to the water is not worth the cost and water blanching is sufficient. Differences in the drying rate of untreated samples did not imply a noteworthy difference in 
Effect of pre-treatments on kinetics of solar dried grapes $\mid 245$

Table 2: Drying rates and statistical indicators of the normalised Newton model for grapes

\begin{tabular}{lccc}
\hline sample & $k\left(\right.$ day $\left.^{-1}\right)$ & $R^{2}$ & $s$ \\
\hline untreated & $0.1456 \pm 0.01078$ & 0.9390 & 0.0769 \\
blanched in hot water & $0.2038 \pm 0.01652$ & 0.9472 & 0.0747 \\
blanched in 0.1\% oil & $0.2064 \pm 0.01626$ & 0.9506 & 0.0721 \\
\hline
\end{tabular}

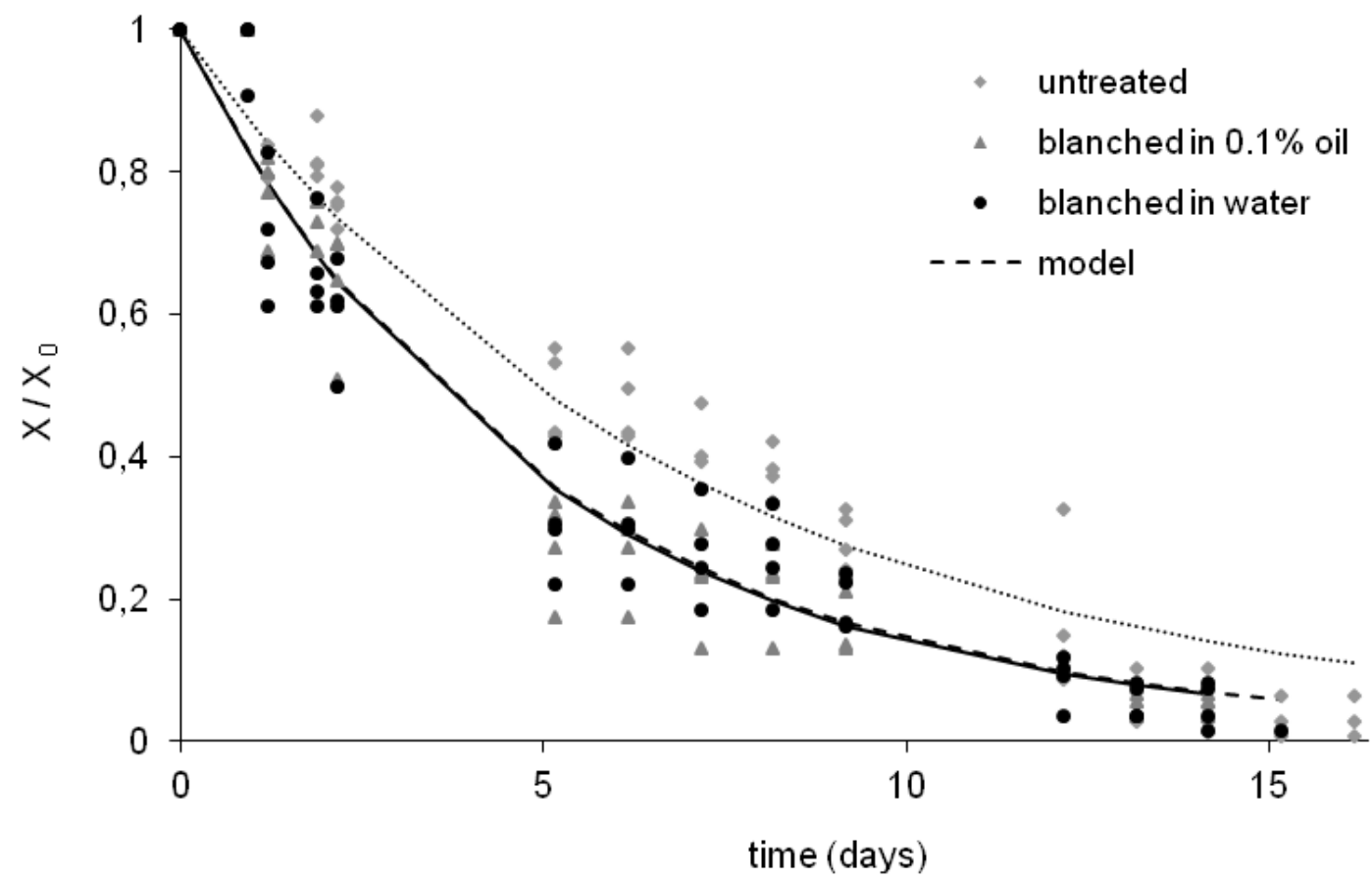

Figure 3: Effect of different pre-treatments on grape drying kinetics

total drying time. Water content of untreated grapes is similar to the water content of blanched ones, in the last drying phase. However, although pre-treatments do not significantly decrease total drying time, they have an important role to prevent the growth of moulds and bacteria, by accelerating the initial drying phase.

Regarding data available in the literature, particularly for grapes, the obtained drying rate values (Newton model) are very similar to the ones presented by Togrul and Pehlivan (2004) and have the same order of magnitude as the ones presented by El-Sebaii, Aboul-Enein, Ramadan, and
El-Gohary (2002). These were the only values found for grapes' drying rates, using the Newton model.

58 Drying rate values presented in this work, are 259 almost one order of magnitude lower than the 60 ones estimated in previous experiments (Ramos, 261 Miranda, Brandão, \& Silva, 2010). Lower drying 262 rates may be attributable to a decrease in blanch263 ing time from 30 to $15 \mathrm{~s}$. Dominga grapes used 264 in the previous experiments were subjected to a $26530 \mathrm{~s}$ water blanching, and experiments performed 266 at 30 and $40^{\circ} \mathrm{C}$ were chosen for comparison. In 267 the present study, the average product temper- 
ature during drying was around $34^{\circ} \mathrm{C}$. However, the two studies are difficult to compare because different grape cultivars and different air conditions drying patterns were used.

\section{Conclusions}

It was found that the normalized Newton model presented the best fit to experimental data for grapes' solar drying. Comparing estimated drying rates of the normalised Newton model, one concluded that samples blanched in hot water or in the $0.1 \%$ edible oil water emulsion had faster drying rates than untreated samples. Contrary to what was expected, it was not observed that pre-treating grapes with the $0.1 \%$ edible oil emulsion increased the drying rate to a higher extent than blanching in hot water.

Pre-treatments enhanced the drying rates, but differences in total drying time were not significant. Although pre-treatments did not significantly decrease total drying time, they play an important role in preventing the growth of moulds and bacteria in the initial drying phase and consequently increasing farmers' income.

Drying rate values are very similar to those reported for grapes in the literature (obtained with the Newton model).

\section{Acknowledgements}

This work was supported by National Funds from FCT - Fundação para a Ciência e a Tecnologia, through project PEst-OE/EQB/LA0016/2011. Inês N. Ramos and Teresa R.S. Brandão gratefully acknowledge, respectively, their PostDoctoral grants SFRH / BPD / 75430 / 2010 and SFRH / BPD / 41419 / 2007 to Fundação para a Ciência e a Tecnologia (FCT) and Fundo Social Europeu (FSE).

\section{References}

Aguilera, J. M., Oppermann, K., \& Sanchez, F. (1987). Kinetics of browning of sultana grapes. Journal Of Food Science, 52(4), 990-\&. doi:10.1111/j. 1365 - 2621. 1987. tb14258.x
AOAC. (2000). Official methods of analysis, 17th ed. vol $1 \&$ 2. Gaithersburg: AOAC International.

Araújo, F., Pascoal, M., Candeias, M., Dias, J., Carvalho, B., \& Machado, B. (1994). Uvas para passas - estudo da sua produção, transformação e comercialização. Mirandela: Direção Regional de Agricultura de Trás-os-Montes.

Bala, B. K. . \& Woods, J. l. (1994). Simulation of the indirect natural-convection solar drying of rough rice. Solar Energy, 53 (3), 259-266. doi:10.1016/0038-092X(94)90632-7

Bennamoun, L. \& Belhamri, A. (2003). Design and simulation of a solar dryer for agriculture products. Journal of Food Engineering, 59(2-3), 259-266. doi:10.1016/S02608774(02)00466-1

Bizot, H. (1983). Using the 'GAB'model to construct sorption isotherms. In R. Jowitt, F. Escher, B. Hallstrom, H. F. T. Meffert, W. Spiess, \& G. Vos (Eds.), Physical properties of foods (pp. 43-54). Essex: Applied Science Publishers.

Box, G. E. P., Hunter, W. G., \& Hunter, J. S. (1978). Statistics for experimenters an introduction to design, data analysis and model building john wiley and sons. New York: John Wiley and Sons.

Doymaz, I. (2005). Sun drying of figs: an experimental study. Journal of Food Engineering, 71(4), 403-407. doi:10.1016/j.jfoodeng. 2004.11.003

Fuller, R. J. (1993). Solar drying of horticultural produce: present practice and future prospects. Postharvest News and Information, $4(3)$.

Grncarevic, M. \& Radler, F. (1971). A review of the surface lipids of grapes and their importance in the drying process. American Journal of Enology and Viticulture, 22(2), $80-86$.

Lahsasni, S., Kouhila, M., Mahrouz, M., \& Jaouhari, J. T. (2004). Drying kinetics of prickly pear fruit (opuntia ficus indica). Journal of Food Engineering, 61(2), 173179. doi:10.1016/S0260-8774(03)00084-0

Mahmutõglu, T., Emir, F., \& Saygi, Y. B. (1996). Sun/solar drying of differently treated grapes and storage stability of dried grapes. 
Effect of pre-treatments on kinetics of solar dried grapes $\mid 247$

Journal of Food Engineering, 29(3-4), 289- 410 300. doi:10.1016/0260-8774(96)00006-4 411

Murthy, M. V. R. (2009). A review of new tech- 412 nologies, models and experimental investi- 413 gations of solar driers. Renewable \& Sus- 414 tainable Energy Reviews, 13(4), 835-844. ${ }_{415}$ doi:10.1016/j.rser.2008.02.010

Pangavhane, D. R., Sawhney, R. L., \& Sarsavadia, P. N. (1999). Effect of various dipping pretreatment on drying kinetics of thompson seedless grapes. Journal of Food Engineering, 39(2), 211-216. doi:10.1016/ S0260-8774(98)00168-X

Peri, C. \& Riva, M. (1984). Étude du séchage des raisins. 1 - effect de traitements de modification de la surface sur la qualité du produit. Sciences des Aliments, 4, 273-286.

Phoungchandang, S. \& Woods, J. L. (2000). Solar drying of bananas: mathematical model, laboratory simulation, and field data compared. Journal of Food Science, 65(6), 990996. doi:10 . 1111/j. 1365 - 2621 . 2000. tb09405.x

Ponting, J. D. \& Mcbean, D. M. (1970). Temperature and dipping treatment effects on drying rates and drying times of grapes, prunes and other waxy fruits. Food Technology, 24 (12), 1403-1406.

Ramos, I. N., Miranda, J. M. R., Brandão, T. R. S., \& Silva, C. L. M. (2010). Estimation of water diffusivity parameters on grape dynamic drying. Journal of Food Engineering, 97(4), 519-525. doi:10.1016/j . jfoodeng.2009.11.011

Riva, M. \& Peri, C. (1986). Kinetics of sun and air drying of different varieties of seedless grapes. Journal Of Food Technology, 21(2), 199-208.

Saravacos, G., Marousis, S., \& Raouzeos, G. (1988). Effect of ethyl oleate on the rate of air-drying of foods. Journal of Food Engineering, 7(4), 263-270.

El-Sebaii, A. A., Aboul-Enein, S., Ramadan, M. R. I., \& El-Gohary, H. G. (2002). Empirical correlations for drying kinetics of some fruits and vegetables. Energy, 27(9), 845-859. doi:10 . 1016 / S0360 - 5442(02) 00021-X

Striegler, R. K., Berg, G. T., \& Morris, J. R. (1996). Raisin production and processing
(L. P. Somogyi, H. S. Ramaswamy, \& Y. H. Hui, Eds.). Processing Fruits: Science and Technology - Major Processed Products (pp. 235-263). Lancaster: Technomic Publishing.

Togrul, I. T. \& Pehlivan, D. (2004). Modelling of thin layer drying kinetics of some fruits under open-air sun drying process. Journal of Food Engineering, 65(3), 413-425. doi:10.1016/j.jfoodeng.2004.02.001

Vázquez, G., Chenlo, F., Moreira, R., \& Carballo, L. (1999). Desorption isotherms of muscatel and aledo grapes, and the influence of pretreatments on muscatel isotherms. Journal of Food Engineering, 39(4), 409-414. doi:10 . 1016 / S0260 8774(99)00030-8

Whiting, J. (1992). Harvesting and drying of grapes (B. G. Combe \& P. R. Dry, Eds.). Viticulture - practices. Adelaide: Winetitles.

Williamson, G. \& Carughi, A. (2010). Polyphenol content and health benefits of raisins. Nutrition Research, 30(8), 511-519. doi:10. 1016/j.nutres.2010.07.005

Yaldiz, O., Ertekin, C., \& Uzun, H. I. (2001). Mathematical modeling of thin layer solar drying of sultana grapes. Energy, 26(5), 457-465. doi:10 . 1016 / S0360 - 5442(01) $00018-4$ 